\title{
Research on the Innovative Mode of Undergraduate Tourism Management Talents Training in Jiangxi Province
}

\author{
Liqin Zhang \\ Jiangxi Science \& Technology Normal University, Nanchang, Jiangxi, 330038
}

Keywords: Undergraduate Tourism, Talents Training Management Model, Innovation Study

\begin{abstract}
With the rapid development of China's tourism industry, tourism enterprises are faced with the status quo of lacking talent. Innovative application of undergraduate tourism management professional personnel training can alleviate the lack of talent in China's tourism enterprises to improve the undergraduate tourism management professional industry employment rate, to achieve personnel training and business talent needs of the seamless docking. This paper analyzes the existing problems in the training of undergraduate tourism management talents, and puts forward that the training of undergraduate tourism management talents should be guided by innovative thinking and cultivate the reform and teaching team under the premise of clarifying the market orientation of talent cultivation Construction, the introduction of "scene" class, the creation of virtual tourism enterprises, to achieve the practical value of personnel training.
\end{abstract}

\section{Introduction}

Personnel training usually referred to as the training of the school personnel, it is the school's talent training to take some kind of personnel training measures to enable personnel to cultivate the object (students) physical and mental changes in line with the purpose of change activities. In the process of personnel training, training objectives and training measures are two essential and important factors. The so-called model, generally refers to the stability of the existence, sustained play and repeat the behavior of the way, refers to the formation of a standard or people can do according to the standard style. Obviously, the mode of personnel training refers to a relatively stable structure state and operation mechanism under the guidance of certain educational ideas (ideas) to achieve certain training objectives (including training specifications) in the process of cultivation. It is a series of elements of the organic combination, in practice to form a certain style or characteristics.

According to the extension of the division, personnel training model can be divided into the whole of the overall model and a specific professional model and other levels. But no matter what kind of talent training model, its content should be related to personnel training objectives and personnel training measures in two ways. Or it can be said that to build a talent training model, the specific content should mainly consider the objectives of personnel training and personnel training measures how to build. Talent training objectives is, cultivators to cultivate the quality of personnel and specifications of the general requirements. Is the training of personnel training standards and requirements, is the core of personnel training model construction, personnel training activities with regulation, norms, guiding role. Personnel training measures, it is to achieve the goal of personnel training and approach. It mainly includes personnel training content, personnel training means, personnel training system, personnel training evaluation four aspects. To discuss the reform of personnel training model, the focus should be on the above personnel training objectives and personnel training measures two aspects. 


\section{Objectives of the Tourism Management Personnel Training}

With the development of our national economy and society, the demand for tourism management personnel is increasing. In addition to the traditional demand for grassroots service personnel, the demand for senior management talents is more urgent. From the level of tourism education, the secondary education is mainly grass-roots service personnel, tertiary education is the main training of low-level management of tourism enterprises and front-line operators, undergraduate education to train the tourism enterprises in the senior management Personnel, master, doctoral education is the main training at all levels of tourism administrative departments, senior management of tourism enterprises and tourism high, secondary education unit educators. It can be seen that the task of cultivating senior management talents in tourism enterprises is mainly done by tourism undergraduate education. Therefore, the tourism management undergraduate professional in the clear goal of personnel training, on the one hand should teach students the professional management of tourism management knowledge, on the other hand should enhance the students during school experience, improve students' knowledge acquisition ability, learning ability and practical ability Multi-one integrated quality. During the school period to complete the internship from low to high layer by layer exercise, from the first grade semester to use part of the holidays into the enterprise to carry out post work, after three and a half years of study and exercise, most graduates can become a graduate Enterprise frontline staff, and gradually realize the goal of cultivating professional managers, to achieve high employment goals.

\section{Construction of the Undergraduate Tourism Management Talents Training Model}

After 30 years of development, China's higher tourism education has accumulated a lot of successful experience, but there are also some problems: a large number of tourism colleges and universities (Department, professional) is still confined to the traditional teaching model, to cultivate what type of talent (service operation Talent, grass-roots management talent, senior management personnel, or theoretical research talent), the goal is not very clear positioning, so that the teaching plan, curriculum targeted poor, the actual content of the teaching and the actual dislocation of the industry, cultivated talent in the knowledge structure , The capacity structure is difficult to adapt to the job requirements of the tourism industry, far from the formation of the Lausanne Hotel Management Institute, the United States Cornell University as a distinctive school characteristics and school model, and in the industry by the widely recognized brand institutions. This prompted us to use new thinking and vision to find a solution to the concept of education, personnel training and other aspects of a series of reforms.

The goal of training is the positioning of knowledge ability, determines the pattern of personnel training, determines the different teaching materials, teaching methods, curriculum and so on, but also to a large extent determine the employment direction of graduates and career orientation. Too high training objectives and too wide professional settings will lead to students learning objectives are not clear, professional is not prominent, ideological instability and other issues; too theoretical and academic training direction, leading to the lack of professional skills and vocational skills The weak. In its opinion on implementing the spirit of the 17th CPC National Congress, the National Tourism Administration needs to emphasize the need to cultivate a multi-level and multi-disciplinary, focusing on applied and highly skilled talents, according to China's tourism talent market Of the tourism talent team, which applies to the overall orientation of China's tourism education. China's Ministry of Education issued by the ordinary colleges and universities undergraduate professional directory and professional introduction, the tourism management professional undergraduate business training objectives to make the following provisions: the professional training with tourism management expertise, at all levels of tourism administration, tourism enterprises Units engaged in tourism management work of senior specialized personnel. However, the reality of tourism management professionals engaged in tourism management work of senior specialized personnel understanding is vague. As most of the tourism enterprises in the initial 
recruitment of college students are provided when the grassroots positions, so some people think that tourism management is not a senior professional training, but the tourism business of intermediate talent. This is actually confused with the classification of talent in the education system and the classification of professional jobs. Higher education is the training of senior specialized personnel, rather than intermediate talent. As for the talent at the time of the initial application or after a period of time, it is in the comparison of grass-roots positions or senior management positions and it is the job of these personnel adaptability. As Tsinghua University is the cradle of the engineer, but its graduates can not get out of school to become an engineer, nor does it prevent its graduates from becoming leaders. Tourism management undergraduate training goal is to train in the tourism management work of senior specialized personnel, which is no doubt. It is true that the cultivation of tourism talents can be done in different categories, disciplines and different levels. Higher education in developed countries is also a distinctive feature. It should be based on the analysis and study of international tourism talent training mode, analysis of tourism talent supply and demand situation, combined with the school's own actual positioning training objectives, so that training objectives more specialized and clear. In fact, since the 20th century, 90 years, China's hotel industry has long been entered by the professional managers of the era of management, but did not cause the attention of our universities and attention. Travel agency industry, tourism industry, leisure and entertainment industry and exhibition industry are also synchronized into the era of tourism management professional managers. Tourism Management Higher Education Must Enable the Training Mechanism of Professional Managers.

In this teaching system, practical teaching as an important part of the teaching system, breaking the class and extracurricular, semester and holidays, schools and business boundaries, free enough time to increase students to business internship time, established Complete ladder practice teaching system, that is, industry awareness, school simulation training, tourism enterprises internship, star hotel graduation practice combined, multi-form, multi-channel training students practical ability. Among them, the tourism industry awareness is the entry of professional quality of the internship, to improve the students to eat, live, travel, travel, shopping, entertainment six elements of the perceptual knowledge. School simulation training, learning the main skills of the professional, including hotel operating skills, tour guide skills, etc., generally in the school's school training center, so that students more solid grasp of professional skills. Tourism enterprises are focused on different types of tourism enterprises to exercise the professional ethics of students, through the hotel, travel agencies, tourism scenic spots in the field practice, training and improve the spirit of service and awareness of students, and develop professional ethics The At the same time, we should pay attention to correct the deviation of students' thinking and improve the psychological quality of students. Star hotel graduation practice, mainly in the tourism hotel grassroots department management positions to carry out internships, more focused on nurturing students basic management quality and ability, comprehensive testing students nearly four years of knowledge and ability. Each part of the internship, both with the theory of teaching, but also with the tourism business season is consistent, not only the theory of teaching notes and examples, but the skills and practical ability to cultivate one way to cultivate practice and innovation Ability as the main goal, self - contained.

\section{Conclusion}

Tourism strategic pillar industry put forward to the tourism industry to bring new opportunities for development, but also to the university tourism management professionals to raise new challenges to promote the application of undergraduate majors must be at a higher level to explore the reform of higher tourism education and Development "based on the positioning of applied tourism management personnel, this paper defines the stakeholders involved in tourism management and builds a model of tourism management personnel with the participation of stakeholders. Among them, the core stakeholders there are six main interactions between tourism faculties, students and tourism enterprises: interaction between industry and academia, two-way selection, order training, two tutor system, individual teaching, high docking, edge core 
stakeholders are mainly The training mode of tourism management personnel is a useful attempt in the reform of applied undergraduate education in our country. It aims to play a role in attracting tourism, leading the tourism industry, the business community, the tourism industry, the tourism industry, the tourism industry, the tourism industry, the concern of the community, and jointly improve the quality of tourism professionals in China offer advice and suggestions power.

\section{References}

[1] Li Bingyi. Application of applied undergraduate tourism management talent training model [J]. Journal of Jiangsu University of Science and Technology, 2009 (04)

[2] Hong Caizhen. Students - the core stakeholders of higher education [J] .Heilongjiang Higher Education Research, 2006 (12)

[3] Zhang Jie. Some basic problems of strategic management in colleges and universities [J]. Education Research, 2006 (11)

[4] Zhang Yi, Zhang Rui. Stakeholder management in colleges and universities: a research framework [J]. Science and Technology Management Research, 2006 (03)

[5] Long Xianqiong. The historical evolution of university talent training model [J]. Journal of Educational Science of Hunan Normal University, 2006 (01) 